\title{
Tax Planning On Value Added Tax (VAT)
}

\author{
Anto*, Moina* \\ * Master of Administration Science Students - Tax Management - Instute STIAMI \\ DOI: 10.29322/IJSRP.11.06.2021.p11440 \\ http://dx.doi.org/10.29322/IJSRP.11.06.2021.p11440
}

\begin{abstract}
This research is aimed to evaluate tax planning on value added taxes (VAT). Taxes have been the biggest contributor and revenue of a nation income which will be utilized to pay for the nation's needs and control the wheels of its economy and growth. In tax planning, corporations can stipulate tax planning on Value Added Tax (VAT). Value Added Tax (VAT) is the tax which is imposed on value increment on goods and/or services from producers to consumers.
\end{abstract}

Index Terms- Tax planning, Value Added Tax (VAT)

\section{INTRODUCTION}

$\mathrm{T}$ axes have been the biggest contributor and revenue of our nation income which will be utilized to pay for the nation's needs and control the wheels of our economy and growth. Tax revenue in State Budget "APBN" in 2015 reached Rp1.201.7T (Kementerian Keuangan, 2015), of which VAT plays a major role, surpassing $43 \%$ of the total of tax revenue. VAT is the tax which is imposed on the increment of value added in the event of transfer of goods and/or services from producers to consumers.

The source of law that is used in VAT application in Indonesia is UU No.42 Tahun 2009. Since the calculation, recording, payment and submission of VAT are performed by the producers or sellers, the term of "Taxable Entrepreneurs" (PKP) comes to place. In the calculation of owed VAT by taxable entrepreneurs, the terms of "Output VAT" and "Input VAT" are known. The purpose of enterprises or sellers is to gain the maximum profit on their businesses. Thus, tax planning can be used as a step to minimize tax expenses and increase profit.

\section{LITERATURE REVIEW}

Tax

According to Soemitro in Mardiasmo (2006:1), taxes are obligations of citizens to their country based on laws (can be forced), which will be used to finance general expenditure of the country without direct benefits in return.

\section{VAT Definition}

According to Undang-Undang Nomor 42 Tahun 2009, Value Added Tax ("VAT") is the tax on consumption of goods and services in customs area which is imposed gradually in every production and distribution line. VAT is categorized as an indirect tax since it is collected by the producers, whom is not the tax bearer, on behalf of the end users or consumers.

\section{Taxable goods}

Taxable goods are tangible goods, which based on its nature or law in the form of moveable/immovable goods and intangible goods which are subjected to tax based on UU No. 8 Tahun 1983 Pasal 1 ayat 2 dan 3.

\section{Taxable entrepreneurs}

Based on pasal 1 angka 15 UU PPN 1984, which was cited by Pohan (2016: 68), taxable entrepreneurs are entrepreneurs who transfer taxable goods or services, exclude small entrepreneurs, except if the small entrepreneurs choose to be registered as taxable entrepreneurs based on pasal 3(PMK 68/PM K.03/2013).

\section{Tax Management}

Suandy (2016:7) stated that the objective of tax management could be obtained through its functions, including:

\section{Tax Planning}

As the first step in tax management, tax planning is performed by data accumulation and research of tax regulations to analyze the relevant factors that could be utilized in order to choose the appropriate tax saving alternatives.

\section{Tax implementation}

In this stage, the factors discovered in the previous stage are implemented formally and materially.

\section{Tax control}

Tax control is intended to ensure that tax obligations have been performed according to the plan and have fulfilled formal and material requirements. The essential element in tax control is audit of tax payments.

\section{Tax planning on VAT}

Suandy (2013:12) declared that tax planning, especially VAT, could be performed by maximized the Input VAT. Enterprises should choose the taxable entrepreneurs to obtain taxable goods or services. Consequently, the amount of Input VAT that can be credited against the Output VAT is increased. On top of that enterprises can postpone the tax invoice in a period of 1 month of transfer of taxable goods and/or services. Input VAT that can be credited must directly connected to production, errors in distribution, marketing and management of the taxable goods or services and the tax invoice is the standard tax invoice or other document that is accepted as standard tax invoice's substitution. As one the tax planning method, tax planning on VAT is performed in order to avoid overpayment of VAT. This overpayment may occur due to the followings: 
1. The amount of Input VAT paid exceeds Output VAT in one tax period which can be caused by purchase/import of taxable goods or services including capital expenditure for investment or business commencement period, export of taxable goods/services, transfer of taxable goods/services to VAT collector, transfer of taxable goods/services which are categorized as "Non-Collected VAT" goods/services.

2. Errors in VAT collection. This event is widely known as surplus in tax payment due to payment of error VAT collected.

Others tax planning includes the followings:

1. In the event of asset acquisition including building, taxable enterprises should avoid self-build activities (Kegiatan Membangun Sendiri "KMS"). Exporters are also advised to be registered as taxable entrepreneurs.

2. For those qualify the requirements as Entreport entrepreneurs for export purpose (Pengusaha Entreport Produksi Untuk Tujuan Ekspor "EPTE"), it will be more efficient to be registered as taxable entrepreneurs-EPTE (Mitra Konsultindo, 2015).

\section{The fundamental aspects in performing VAT planning}

1. Payment postponement.

Taxable entrepreneurs can postpone VAT payment until the following month by producing standard tax invoice in the following month of transfer/transaction.

\section{Expensing}

Non-taxable entrepreneurs can expense the Output VAT in the financial statement in order to decrease other tax expense.

\section{International Tax Planning}

The planning in trans-border transactions emphasizes on the factors that could affected international transactions. Other currencies, such as USD \$ are used in international transactions in import activities. However, the nominal would be calculated in Indonesian Rupiah using the stated exchange rate which has been set by the Directorate General of Customs and Excise "DJBC". Therefore, enterprises do not exercise any special international tax planning.

\section{CONCLUSION}

VAT planning can be performed through some methods including payment postponement and expensing. Tax invoices can be delayed and dated in the following month of the transaction in payment postponement method. The purpose of this treatment is to accumulate Input VAT, which can be compensated and restituted. The higher the Input VAT, the higher the amount of restituted VAT. For entrepreneurs who do not qualify to issue tax invoice, expensing method could be chosen as alternative to decrease its tax liabilities.

Tax planning is advised to be performed by enterprise as a mean to minimalize tax expenses. This strategy should be audited and carefully evaluated each year to ensure its appropriateness and effectiveness.

\section{REFERENCES}

[1] Andromedha Daud, Harijanto Sabijono, Sonny Pangerapan (2018). Analisis penerapan pajak pertambahan nilai pada pt. nenggapratama internusantara, Jurnal Riset Akuntansi Going Concern 13(2), 2018, 78-87.

[2] Azizah ,Efa Lutfi. Konsep perencanaan pajak atas pajak pertambahan nilai.

[3] Atmojo, M., Rahayu, S., Budihardjo, O. (2016). Analisis Penerapan Perencanaan

[4] Pajak Pertambahan Nilai (Studi Kasus Pada CV Guyub Rukun Putra Sakti

[5] Tahun Pajak 2014). Jurnal Perpajakan (JEJAK), Vol. 8, No. 1., Hal. 1-11

[6] Mangoting, Y. (1999). Tax Planning: Sebuah Pengantar sebagai Alternatif

[7] Meminimalkan Pajak. Jurnal Akuntansi dan Keuangan, Vol. 1, No. 1, Hal

[8] 43-53

[9] Margono. (2007). Metodologi Penelitian Pendidikan. Jakarta : Penerbit Rineka Cipta.

[10] Mayang Hapsari, Mochammad Djudi, Suhartini Karjo. Evaluasi perencanaan pajak pertambahan nilai pada pt. "x" di kabupaten kediri, Jurnal Perpajakan (JEJAK),Vol. 6 No. 22015

[11] Mildawati, T. (2013). Penerapan Tax Planning PPN dalam Penghematan Beban Cash Flow di CV. MMM. Jurnal Ilmu \& Riset Akuntansi, Vol. 2, No. 8., Hal. 1-21.

[12] Mitra Konsultindo. 2015. Prinsip-prinsip dalam melakukan perencanaan Pajak Pertambahan Nilai. http://taxconsultingjakarta.com/. (diakses tanggal 13 Februari 2015, pukul 17.00 WIB).

[13] Pohan, Chairil Anwar. 2011. Optimizing Corporate Tax Management: Kajian Perpajakan dan Tax Planning-nya Terkini. Jakarta: Bumi Aksara.

[14] Resmi, S. (2013). Perpajakan Teori dan Kasus. Edisi Keenam. Jakarta: Penerbit Salemba Empat.

[15] Suandy, Erly. 2013. Perencanaan Pajak Edisi 5. Jakarta: Salemba Empat.

[16] Zain, M. (2007). Manajemen Perpajakan. Edisi Ketiga. Jakarta: Penerbit Salemba Empat

[17] Zain, M. (2007). Manajemen Perpajakan. Edisi Ketiga. Jakarta: Penerbit Salemba Empat.

[18] http://jimfeb.ub.ac.id/index.php/jimfeb/article/download/4515/3961

[19] https://media.neliti.com/media/publications/193740-ID-analisis-penerapanperencanaan-pajak-pph.pdf

\section{AUTHORS}

First Author - Anto, Master of Administration Science Students - Tax Management - Instute STIAMI, antolim37@yahoo.com

Second Author - Moina, Master of Administration Science Students - Tax Management - Instute STIAMI, moina.lie08@gmail.com 